\section{“Too little, too late" for AZT}

\section{Washington}

A FLURRY of recent legal challenges to Burroughs Wellcome's exclusive patent for the AIDS drug AZT may eventually wrest control of the patent from the pharmaceutical company, but the efforts have come too late significantly to lower the price of drug in the next year or two, when it is needed most, AIDS activists say.

Three challenges in the past several months have fuelled speculation that Wellcome will soon have to concede that US government and university scientists had a pivotal role in discovering and developing AZT and thus deserve part-ownership of the patent rights. Lawsuits by the generic drug company Barr Laboratories and the consumer group Public Citizen, on behalf of the People With AIDS Health Group and several AIDS patients, are seeking to overturn the company's patent. The National Institutes of Health (NIH), whose scientists first discovered that AZT is effective against AIDS in 1985, last month released a statement criticizing Wellcome for taking undue credit for the drug.

Although NIH have not yet decided to sue on their own behalf, agency lawyers are considering joining one of the other suits as a supporting player.

Although some of the challenges may eventually meet with success, activists say that none appear likely to change the pricing picture for AZT in the near term. The Public Citizen suit is likely to fail on "standing" grounds - consumers are usually not considered eligible to challenge a patent. Barr's suit has no standing problem, but, like any patent challenge, it is likely to take years to decide. "We're looking at a legal process so long," warns Derek Hodel of the PWA Health Group, "that the issue will be moot by the time it's settled." The NIH statement, meanwhile, coming nearly two years after government researchers first publicly criticized Wellcome for taking credit for $\mathrm{AZT}$, is probably "too little and too late" to influence matters much now, says Jeff Levi, director of government affairs for the AIDS Action Council. He notes that although NIH lawyers have been considering legal action since last year, they have so far made no effort to follow through with an actual lawsuit. Last month's statement, by NIH director Bernadine Healy, is little more than an official endorsement of a dissenting position that NIH scientists have taken since the government granted Wellcome a patent for the drug in 1988.

Rather than holding out hope for success in the courts, AIDS activists believe that industry competition - in the form of new drugs - will be the factor that finally cuts the costs of AZT.

This fall, the Food and Drug Agency is expected to approve DDI and DDC, two new drugs for the treatment of AIDS.
Although initial clinical trial results suggest that neither drug is significantly better than AZT, the simple presence of three drugs from three different pharmaceutical companies will probably trigger a drop in prices. AZT currently costs between $\$ 2,200$ and $\$ 2,800$ for a yearly supply.

Last year, two Canadian drug companies decided to challenge the Wellcome monopoly by manufacturing AZT and selling it through outlets in the Bahamas, where Well-

\section{London}

THE ceremonial opening last Friday by the Princess Royal of a new building at Bristol to house the funding councils for both British universities and polytechnics may have turned out to be symbolic of the government's plan to merge them, but most other questions provoked by last month's announcement (see Nature 351, 257; 1991) have not yet been decided.

The overriding problem is that most of the planned changes will require legislation, and that the government must call a general election in not less than 12 months from now. Even if legislation were introduced in the parliamentary session due to begin next November, there might not be time for its enactment.

The government's intention seems to be to introduce in November legislation to allow for the transfer of further education colleges from local authority control to that of funding councils yet to be formed, as well as for its system of proposed National Vocational Qualifications. The proposals affecting universities and polytechnics would be introduced only after the next election (when the present government may no longer be in office).

Even the planned merger of the two funding councils, themselves established by the Education Reform Act of 1988, is in limbo, the new building notwithstanding. A spokesman for the Department of Education and Science said this week that the transitional arrangements had not yet been worked out. The government's intention is that the new funding council should be operating from 1 April 1994.

The appointment of Lord Chilver as chairman of the Universities Funding Council (UFC) terminates in November, but no decision has yet been made about his continuation even as a caretaker.

The notion that the merged funding council should then be divided into national entities is a further source of confusion. The planned separate funding council for Scotland is regarded even by academics at English universities as inevitable.

But there is anxiety about the intended come does not have a patent (see Nature 349, 93; 10 January 1991). They are charging about two-thirds of the Wellcome price. But the move has had little effect on US users because so far no one has been willing to bring the drug into the United States for resale. "We have no plans to import AZT at the present," says Hodel. "Part of our purpose in filing our suit is that the Burroughs patent infringement suit [against the two Canadian companies] prevents it." But without the legal clout of NIH, "there's not much light at the end of the tunnel," he says.

Christopher Anderson \& Dlane Gershon

\title{
British move sows confusion
}

separate funding council for Wales, which includes one federated university and one polytechnic. There are also a further six higher education institutions now controlled by local education authorities which are due to be taken over by the Welsh Office from 1 April next year, together with responsibility for the Welsh polytechnic.

Both in Scotland and Wales, there are fears that continuing support for academic institutions is unlikely to match the support they now receive for research from the research councils. In Wales, the small size of the proposed system is a further cause for concern.

But the most common anxiety among British academics centres on research funds. The government is at present working on a scheme by which some funds would be transferred from the UFC to the research councils, which would then (from September 1992) pay directly attributable overhead costs (but not researchers' salaries) to grant recipients.

The Department of Education and Science will announce in the autumn its response to a proposal by the Advisory Board for the Research Councils that the sum transferred should be more like $£ 150$ million than the $£ 100$ million already announced.

The most serious fears among university researchers stem from their knowledge that the enhanced status of the polytechnics, will lead them to expect a greater proportion of the available research funds, so that the funds available will be more thinly spread.

Meanwhile, while awaiting the promised legislation, polytechnics are having fun choosing names for the universities they will be allowed to be under the new regime. The Polytechnic of Central London seems determined to be the University of Westminster, many polytechnics in cities with a university already (such as Leeds, Leicester and Nottingham) may become the "city university" thereof, while the Oxford Polytechnic may become the "new university" of the same name.

John Maddox - Labour Party pre-empted on polytechnics: see page 512 . 